JOURNAL OF EDUCATIONAL REVIEW AND RESEARCH

e-ISSN: 2597-9752 dan p-ISSN: 2597-9760

This work is licensed under

a Creative Commons Attribution-NonCommercial 4.0 International License.

\title{
Policy Evaluation Total Quality Management (TQM) School Applying International Organization for Standardization (ISO) in the City of Samarinda
}

\author{
Azainil $^{1}$, Nurul Ulfa Apriliani ${ }^{2}$, Suandie $^{3}$ \\ Faculty of Teacher Training and Education, Mulawarman University, Indonesia ${ }^{1,3}$, \\ Postgraduate of Educational Management, Mulawarman University, Indonesia ${ }^{2}$ \\ azainil@fkip.unmul.ac.id ${ }^{1}$, ulva.aprilia2@gmail.com ${ }^{2}$, sumuka1890@gmail.com
}

Keywords

Policy, TQM, School, ISO

\section{ABSTRACT}

This policy evaluation research to find out the need, implementation and achievement result of TQM in Vocational High School applying ISO.This research is a policy evaluation research, with qualitative research method. Qualitative research method is a research method used to determine natural condition (naturalistic), where the researchers are as a key instrument, data technique in triangulation. Data analysis with inductive and more.This policy evaluation study examines the TQM policy documents required for schools implementing the ISO. The evaluation model uses the Context, Input, Process and Product (CIPP) model developed by Stuffebeam. Component Criteria. From the vision statement. The input components of the curriculum, financing, facilities and infrastructure, educators and educators as well as students, curriculum preparation process components, teaching materials, teaching and learning process and assessment, while product / output components of student satisfaction, student achievement and school performance implements TQM ISO.Research result. TQM ISO-based schools need to be implemented, both schools have the formulation of vision, mission, goals and restra. The input components of all schools have implemented the 2013 curriculum, discipline, sufficient facilities and infrastructure, educators and educators are in accordance with standards and there are standards of acceptance. The process component shows all teachers have been preparing syllabus, lesson plan and teaching materials, and teaching and learning process and assessment according to the standard. Existing Product / Outputs. Students, student achievement and achievement in applying ISO 9001-2008 well.Suggestions of these results are (1) improvements from the TQM ISO understanding for all stakeholders, (2) need also from the same language, and (3) improve the ISO-based TQM with commitment improvement, paradigm shift, mental attitude and organizing the guarantee system quality. 


\section{INTRODUCTION}

\section{Background}

In order to achieve the progress of the nation, Indonesia needs quality human resources, because our nation will not be able to compete with other countries without having qualified resources. To face the demands of current tasks and to respond to future challenges, the development of human resources is needed. Strict global competition so that requires human resources who have adequate competence as well as high quality. In improving the quality of human resources, education plays an important role. Therefore the main function of education is to prepare learners (future generations) with the skills and skills necessary to have the ability and readiness to jump in the middle of society. Education is a strategic means to improve the quality of a nation, because the progress of a nation can be measured from the progress of education.

Recognizing the importance of the process of improving the quality of human resources, the government together with the private sector have jointly and continuously strive to realize the mandate through various educational development efforts of higher quality, among others through the development and improvement of curriculum and evaluation system, improvement of education facilities, development and procurement teaching materials, and training for teachers, lecturers and other education personnel.

Thus, educational institutions should strive to make the steps of professional educational innovations with reliable management, so that educational institutions can print reliable cadres in the midst of society, well, ready in intellectual, skill, and spiritual . So with a variety of diversity, educational institutions should be able to take care of itself in accordance with the environmental conditions and needs of students so that the resulting output is really in accordance with what is expected by consumers.

With this approach, the spearhead of efforts to improve the quality of schools lies in the school itself. When the government gives the school authorities the opportunity to optimize their potential for various ways, one of them is by applying Total Quality Management (TQM) in education to achieve the desired quality of education. As Fandi Tjiptono stated, (2003: 4) that: TQM is an approach in running a business that tries to maximize the competitiveness of an organization through continuous improvement of its services, labor, process and environment.

TQM is a management approach at an institution, focused on quality and based on the participation of the entire human resource and is aimed at long-term success through customer satisfaction and benefits to members of its human and community resources institutions. The TQM process has specific inputs to customers' wants, needs, and expectations, processing inputs in institutions to produce goods or services that in turn satisfy customers. TQM's main goal is the continuous improvement of service quality.

Thus Quality Management itself must be implemented continuously. TQM is an effort to create a quality culture, which encourages all staff at an institution to satisfy customers. Entering the era of globalization, the role of the world of education becomes more important and decisive, because with education that is identical to the progress of science and technology will be mastered. With the mastery of science and technology progress and prosperity of the nation can be achieved, which must be supported by the availability of quality human resources one of which depends on the quality of education.

Various improvement efforts in the field of education, namely from central-based quality improvement management towards school-based quality improvement. School-based quality improvement management is a management model that provides wider autonomy to schools and encourages participatory decision-making involving all school members, whether principals, teachers, employees or students and the community, whether parents or related parties with the existence of a 
school. Without putting aside the other components, the principal figure is most instrumental in determining school goals and education in general (Mulyasa, 2002: 216).

For that SMK which is a vocational education and one of the sub-system of education should also be developed and upgraded to anticipate future needs and challenges as well as the needs of the business world / industry, the development of the work world and the development of science and technology (Depdiknas: 2004; 5) . There are various types and levels of education, one type of formal education at the level of Senior High School (SLTA) is Vocational High School (SMK). In the framework of socialization as well as to improve the quality of SMK, then since enacted the SMK 2004 Curriculum, Director of Dikmenjur Depdiknas RI recommend to all SMK who have been able to apply qualitybased management by obtaining certificate of International Standard Organization (ISO).

ISO is a form of international recognition of products or services that have international standard quality. In this case, SMK graduates can be absorbed in the work market both national and international (Dikmenjur, Depdiknas 2004). The quality management system of ISO 9001: 2008 is a quality management system to maximize the competitiveness of an institution focusing on improving the process for customer satisfaction (BSN, 2008: 5).

The process of achieving a quality management system is well controlled, so it can be ensured that the quality offered to customers (students, parents, government, business or industry as the institution of industrial practice, and the business world or industry as graduate recipients) done and proven.

Implementation of quality management system (SMM) ISO 9001: 2008 as the front institution in education activities is needed. This thinking is in line with the clauses in ISO 9001: 2008 quality management system which include: improvement of education quality management responsibility, human resources management, product realization management in the form of graduates who have qualified competence and able to compete in the era of free market as the demands globalization as well as control, monitoring and measurement of improving the quality of education in the future (BSN, 2008: 9-2).

Based on Outlines of the 2012 Vocational Coaching Program Dirjendikmen (2012: 19-21) states that for the purpose of measuring the achievement of the strategic objectives of vocational secondary education development required a number of strategic targets that describe the conditions to be achieved in 2014. One of its strategic goals is as much as 70 \% SMK is ISO 9001: 2008 certified in 2014. Performance indicator of Directorate of Vocational Training on achievement of 2009 shows that SMK which is ISO 9001: 2008 certified amounts to 5\%, that number indicates that SMK in Indonesia which is standard ISO 9001: 2008 is still very little.

Thus the authors intend to see how the School evaluates the values of Total Quality Management (TQM) which is the parent science of Quality (as a discipline). While the manifestation of quality terstandard is already achieved ISO 9001-2000 Certificate, so the researcher, this entitled "Evaluation Policy Total Quality Management School implementing ISO in Samarinda City.

\section{Research focus}

This research is evaluative. Whatever the focus of this research is the Evaluation of Total Quality Mangement (TQM) at Samarinda Vocational High School that has implemented ISO standards. The components that will be evaluated at TQM in SMK Samarinda namely: (1) Contingent Component covers the background needs and initial conditions that make School apply TQM standard ISO. (2) Input components include TQM planning at schools, (3) Process Components covering implementation of TQM policies in Schools, and (40 Components of the results of the implementation of TQM policies in Schools.

\section{Formulation of the problem}

Based on the background and focus of the research above, then the problems of this research are; (2) What is TQM's policy planning in schools implementing the ISO ?, (3) How is the implementation of 
TQM implementation in schools implementing ISO ?, and (4) How are the results of TQM implementation in schools implementing ISO? achievements of TQM in schools implementing ISO?

\section{Research purposes}

The purpose of this research are: (1) To know the background of TQM implementation in school, (2) To know TQM policy planning in school, (3) To know implementation of TQM implementation in school, and (4) To know the result achievement of TQM in schools in implementing ISO.

\section{The benefits of writing}

The results of this study are expected to be useful to various parties, among others: (1) For School; can provide information and inputs in an effort to raise awareness of all citizens of the school on the importance of implementing, maintaining and improving the quality of schools through the implementation of TQM standard ISO 9000: 2008 is more leverage for school customers in Samarinda. (2) For the Education Office; Provide information so that it can be used as input material, consideration in decision making and decision making in TQM implementation to school in Samarinda, (3) For Student; Providing information and knowledge about the importance of TQM implementation in School, and (4) For Researcher; Can develop insight and be able to understand the concept and application of TQM system implementing ISO 9001: 2008 in school.

\section{METHOD}

\section{Research design}

This research is a policy evaluation research, which is used qualitative research method. Qualitative research methods mrupakan research method used to examine the condition of natural objects (naturalistic), where penelitia is as a key instrument, data collection techniques triangulation. Data analysis is inductive and qualitative research emphasizes the meaning of generalization.

\section{Place and time of research}

The research place for evaluation of TQM implementation is in schools implementing ISO in Samarinda city, namely SMK Samarinda State Forestry and SMK Muhammadiyah 3 Samarinda. The research time is implemented in the even semester of academic year 2017/2018.

In this study, the study was firstly related to the policy document needed by TQM in SMK Negeri Sutaninda and SMK Muhammadiyah 3 Samarinda. Both the analysis of the substance, the implementation and the result of the TQM policy at SMK Negeri Samarinda and SMK Muhammadiyah 3 Samarinda.

\section{Methods and Design of Research Models}

The policy evaluation model used is qualitative by using naturalistic inquiry method to capture the gap between standard and performance with a more qualitative approach because the researcher will make direct contact with the subject in the field. The research emphasizes the evaluation of TQM implementation policies in SMK. There are two characteristics of qualitative research, the report is very descriptive and the studied is the condition of natural objects. Referring to this understanding, this study will evaluate the implementationTQM in SMK State Forestry Samarinda and SMK Muhammadiyah 3 Samarinda which has implemented ISO 91000 - 2008, to describe the condition of reference criteria (benchmark) with what is based on facts / data in the field. In other words, the researcher will collect data in a reasonable field situation to get the real picture.

The evaluation research model used in this research is using CIPP model developed by Stufflebeam. This evaluation model consists of four components: context component, input component, component of process and product component, with CIPP as model which will be used to evaluate TQM implementation at SMK Forestry State Forestry Samarinda and SMK Muhammadiyah 3 Samarinda. The basis of this evaluation activity through the stages of context, input, process and output. Each component is divided into two namely the description and assessment, namely component evaluation:

a. Context is an effort to describe and detail the background of the need for SMK Forestry State of Samarinda and SMK Muhammadiyah 3 Samarinda to implement TQM. The data required 
to complete the data from the interviews, among others, in connection with the evaluation context, namely: (1) quality policy TQM standard ISO in SMK ?; (2) how the vision, mission and objectives of activities in SMK, and (3) How is the target of human resource quality / commitment in SMK.

b. Input (the period when the policy has not been implemented), This component includes planning implementation of TQM implementation in SMK covering 8 aspects of ISO implementation, that is: (1) Focus on customer; (2) Leadership; (3) Involvement of personnel; (4) Process approach; (5) Management system approach; (6) Continuous improvement; (7) Decision-making based on facts; (8) A mutually beneficial relationship with partners / suppliers. Assessments consisting of standards (criteria used as comparators) and assessments (processes comparing with what is defined, observation by default).

c. Process (the period when the policy has been implemented), encompassing the implementation of standard ISO TQM implementation in SMK, the assessment consists of standards (criteria used as a comparison) and assessment (the process compares with what is done and observation by default).

d. Product (period after policy implemented where data is collected), including desired or predictable results. Observation (data collected at the end of the policy may be a test score and a score). Assessment consisting of standards (criteria used as the basis of comparison), and assessment (the process comparing what is wanted / predicted, observation by default).

\section{Data Collection Techniques and Procedures}

Data collection techniques used are document studies, open and in-depth interviews, observation / direct observation. The data that have been netted are then analyzed using policy evaluation method. Then, the data obtained will be explained descriptively with various approaches and analysis. The documents used in this study are (1) Quality Manual, (2) organizational structure and business process mapping (3) quality policy and quality objectives (4) procedures and work instructions (5) recording quality (6) Restra documents (7) RAPBS and RKAS. In this case the author uses the document that has been owned SMK Forestry State of Samarinda.

\section{Data analysis technique}

Data analysis in qualitative research, conducted at the time of data collection took place, and after completion of collection in a certain period. Miles and Huberman (1984) in Sugiyono (2010: 337) argued that the activity in data analysis is done interactively and continuously so that the data is saturated. the activity can be seen in the following figure:

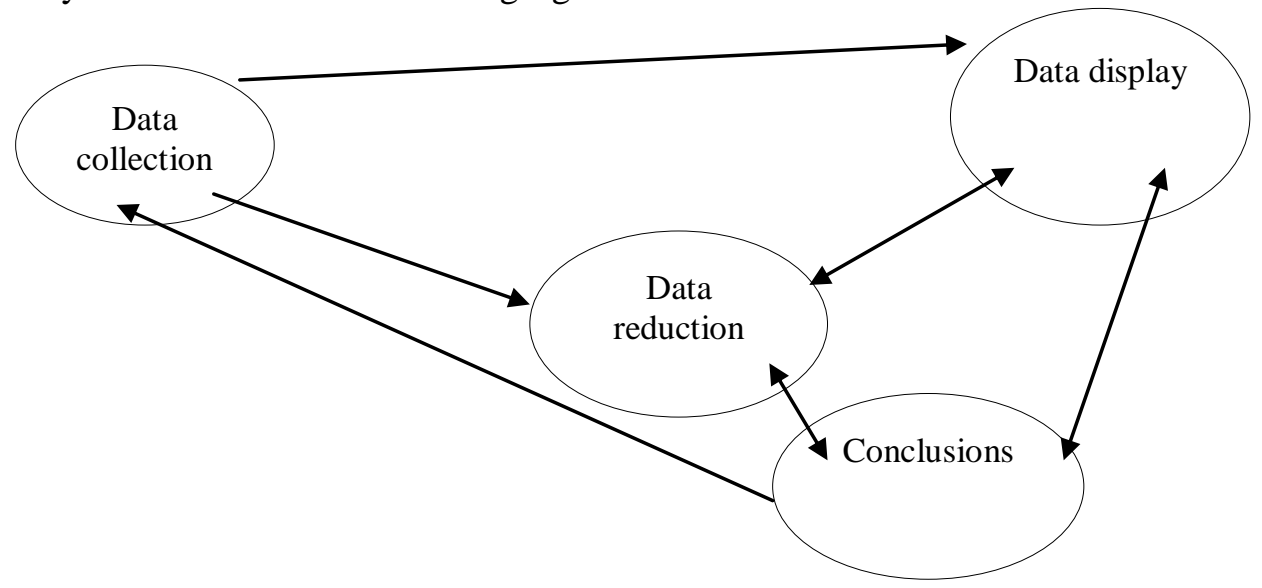

Figure 1. Components in data analysis (interactive model)

Data analysis used in this policy evaluation research is descriptive analysis, that is by using and interpreting data from each indicator component of context, input, process and product / output evaluated. The data of the research are analyzed descriptively by presenting the result of descriptive statistic calculation in the form of frequency table and percentage obtained from the research result. 


\section{Data Validity Check}

To check the validity of the data in order to test the level of trust, can be transferred, reliable and comparable, then used techniques tiangulasi. Triangulation (triangulation) is a data checking technique that takes something from another beyond the data for checking purposes or as a comparison against that data.

\section{RESULTS AND DISCUSSIONS}

\section{A. Results}

\section{Policy Evaluation in Context Components}

The need analysis of TQM Policy in State Forestry SMK Samarinda can not be separated from the existence of Opportunities that affect the implementation of SMK Forestry this. The Needs / Opportunities are:

1. Potential Employment for Graduates Sufficient available for medium-technical forestry workers resulting from SMK Forestry State of Samarinda in the sector of Government, the forestry business and SOEs, jobs that can be entered by these technical personnel include:

a. Government Sector: Forest Ecosystem Controller, Forestry Extensionist, Forestry Police, Forestry Education and Training Instructor, Technical Supervisor (WASGANIS), Litkayasa Technician, Technical Manpower of Forest Management Unity.

b. Private Sector / BUMN Sector: Technical Personnel (Ganis) Sustainable Production Forest Management (PHPL), Secondary Forest Technical Officer.

2. The Opening of Entrepreneurship in Forestry. The policy of the Ministry of Environment and Forestry to develop the utilization of non-timber forest products and environmental services as well as the development of forest management with the community, opening up business fields for the community. SMK Forestry graduates can entrepreneurship is expected to be implemented for graduates:

a. The activities of various forestry businesses such as honey bee cultivation, silkworm cultivation, mushroom cultivation, bidotaya rattan and others is a field of entrepreneurship in the field of forestry that has bright prospects.

b. Can become an entrepreneur of seed and breeder of rare plants

c. Can try in the field of environmental services such as tourism and sports challenges.

3. The existence of Government Policy on Vocational Development. Currently the Government's attention to SMK is getting bigger, it can be seen from the government's commitment to improve the balance of the number of students of SMK which is bigger than SMU. is expected to increase the number of students of SMK, so that will be achieved comparison of $67 \%$ SMK and $33 \%$ SMU. In addition to the consideration of the number of students, the existence of government policies that provide the portion of budget preparation sufficient for the development of SMK is also an opportunity that can be utilized.

4. The existence of the development of Science and Technology. The development of Science and Technology provides an opportunity to improve the quality of SMK Kehutanan. One of the technologies that are now developing is the geographic information system technology (GIS) that is utilized in the forestry field.

5. Availability of work competency standard in forestry field. With the issuance of Standardization of Indonesian National Working Competence in the field of forestry gives direction of designing competency standard of graduates (SKL) for SMK Forestry graduates. Other Competency Standards that can be used to improve the quality of SMK Sutaninda State Forestry are the special standards and international standards.

6. The opening of cooperation in the implementation of SMK Kehutanan. The development of State Forestry SMK Samarinda was implemented by the Ministry of Environment and Forestry together with the Ministry of Education and Culture. In addition to the two ministries, the development of SMK Forestry Samarinda can also involve parties such as developed countries in the field of education, local government, forestry sector companies, state-owned forestry sector. 
TQM Policy needs analysis in SMK Muhammadiyah 3 Samarinda can not be separated from the Opportunities that affect the implementation of SMK Muhammadiyah 3 Samarinda this. The Needs / Opportunities are:

1. Potential Employment for Graduates Sufficiently available for field technical personnel generated from SMK Muhammadiyah 3 Samarinda Government and State-Owned Enterprise and Private Company in the province of East Kalimantan.

2. Manpower needs in the field of electrical power installation engineering in the form of operators of machinery / equipment in factories, planners Installation, Maintenance and Repair, Electronic industry, PLN, Telkom, Electrical Technician, Installation Service, Air Conditioning and Tata, industry service businesses and self-employed.

3. Motor Vehicle Engineering Requirements (Automotive) in all car assembly industries, all car body, service stations, cars and motorcycles, etc. Opening a business (entrepreneurship) in the field of automotive service

4. Heavy Engineering Requirement Heavy equipment Engineering in heavy equipment service company, heavy equipment rental company and All companies or business entities using Heavy Equipment units, Opening business (entrepreneurship) in the field of automotive service of heavy equipment.

With the existence of job opportunities that require highly specialized skills in accordance with their respective fields of expertise such as electrical power installation techniques, Light Vehicle Engineering (Automotive), and Heavy Equipment Engineering, a standard is required in preparing the fieldworker so that it is in the arms once a standardized SMK, in this case the ISO $9001-2008$ standard.

The current Strategic Plan (Restra) of the current Samarinda State Forestry Vocational School is a Renstra of 2015 - 2019 consisting of 6 Chapters, namely Chapter 1 Introduction covering Background, Purpose, Education profile and Legal Basis, Chapter 2 consists of Self-Evaluation covering Environmental Analysis Internal (ALI), External environmental analysis (OT), and SWOT Analysis. Chapter 3 is a Development Program, Chapter 4 Budget Allocation and Chapter 5 Conclusion.

The Strategic Plan (Restra) in SMK Muhammadiyah 3 Samarinda which is in effect now is Renstra 2016-2020 which consist of 5 chapters namely Chapter 1 Introduction which contains about Background, vision, mission and purpose, Chapter 2 on Self-Evaluation by using SWOT analysis , Chapter 3 on development programs and school strategies, chapter 4 on financial budget drafts and chapter 5 cover.

\section{Policy Evaluation in Input Components}

Evaluation of Policy in Input Components related to the implementation of TQM in SMK Forestry State Samarinda and SMK muhammaiyah 3 Samarinda. This evaluation begins with the curriculum applicable in schools.

1. Curriculum SMK Forestry State Samarinda and SMK Muhammadiyah 3 Samarinda Academic Year 2016/2017 has been using Curriculum 2013. Structure The second curriculum of SMK includes compulsory and vocational subjects. In addition programmed local content subject groups tailored to the potential, characteristics and conditions of the region. The two vocational schools have implemented the 2013 curriculum in accordance with the Attachment of Decision of the Director General of Primary and Secondary Education Number: 130 / D / KEP / KR / 201 DATE: February 10, 2017 About Curriculum Structure Vocational Secondary Education

2. Financing In general, the implementation of financial management / financing in accordance with the provisions in school, specifically for SMK Negeri Sutaninda State Forest under the coordination of the Counseling Agency and Human Resources Development Ministry of Environment and Forestry, and in accordance with the Minister of Finance Regulation on Input Cost Standards published every year. For SMK Muhammadiyah 3 Samarinda there are already rules issued by Majlis Elementary and Secondary Education of Muhammadiyah 
Samarinda Regional Executive and poured into Financial Reception Design and Budgetary Use Plan SMK Muhammdiyah 3 Samarinda.

3. The facilities and basic premises in both vocational schools are already available and are sufficiently adequate, both classrooms, workshops, laboratories, Teacher Rooms, UKS spaces, library rooms, and others including religious facilities such as mosques. For SMK Kehutan Negeri Samarinda consists of 11 classrooms, 4 laboratory rooms and 1 library roar has not been added a very residential hostel facilities to occupy about 299 students / students. While for SMK Muhammadiyah 3 Samarinda consists of 10 classrooms, 3 workshops (Tech Workshop Electric Power Installation, Light Workshop Technic Technique, Heavy Equipment Engineering Workshop), 1 Industrial Engineering Electronics lab, Board of School Guard and Students, and others.

4. Educators and Education Personnel To implement the teaching and learning process in accordance with the vision and vision of the school, it requires human resources consisting of Teachers (Teachers) and educational staff consisting of administrative staff, technical personnel, laboratory / workshop, library staff and others. As for educators and education for ledua SMK can be seen in Table 1. Based on Table 1. The number of educators (teachers), both from SMK Forestry State Samarinda and SMK Muhammadiyah 3 Samarinda has met the standards of educators and education, where from 41 0rang teachers in both SMK is based on interviews with the Principal has explained that all teachers have been educated minimum Bachelor degree.

5. The number of students in SMK Forestry State Samarinda and SMK Muhammadiyah 3 Samarinda can be seen in Table 2 .

Table 2. shows that the number of students in SMK Forestry State Samarinda is more than twice that of SMK Muhammadiyah 3 Samarinda, it is evident that public schools are still in great demand by some people in Indonesia, this can be seen from the amount of tuition fees (SPP) of private schools in comparison to public schools and even many public schools are free.

Table 2 shows that in SMK Muhammadiyah 3 Samarinda can be seen that the target amount received is greater than the amount received in the Year 2017, this shows the lack of enthusiasts who want to enter SMK Muhammadiyah 3 Samarinda.

Table 1. Teachers and Education Personnel at SMK Forestry State of Samarinda and SMK Muhammadiyah 3 Samarinda

\begin{tabular}{ccc}
\hline \multirow{2}{*}{ Description } & \multicolumn{2}{c}{ School } \\
\cline { 2 - 3 } & SMK Forestry State Samarinda & SMK Muh.3 Samarinda \\
\hline Teachers & 20 & 21 \\
Education Personnel (staff) & 29 & 4 \\
Total & $\mathbf{4 9}$ & $\mathbf{2 5}$ \\
\hline
\end{tabular}

Source: Documentation of SMK Forestry Stateand SMK Muh.2 Smd, 2017

Table 2. Conditions of Students in SMK Forestry State Samarinda and SMK Muhammadiyah 3 Samarinda TA. 2017/2018

\begin{tabular}{ccc}
\hline \multirow{2}{*}{ Uraian } & \multicolumn{2}{c}{ Number of student } \\
\cline { 2 - 3 } & SMK Forestry State Samarinda & SMK Muh.3 Samarinda \\
\hline Class X & 107 & 61 \\
Class XI & 105 & 36 \\
Class XII & 87 & 40 \\
Total & $\mathbf{2 9 9}$ & $\mathbf{1 3 7}$
\end{tabular}

Source: Documentation of SMK Forestry State and SMK Muh.3 Samarinda, 2017

\section{Policy Evaluation on Process Components}

The curriculum at Vocational High School (SMK) in Samarinda which initially uses the development of various Education Unit Level Curriculum (KTSP) refers to the national standard of education to ensure the achievement of national education objectives. National education standards consist of 
standards of content, process, competency standards of graduates, education personnel, facilities and infrastructure, management, financing, and educational assessment. Two of the eight national standards of education, namely the Content Standards (SI) and the Graduate Competency Standards (SKL) are the main reference for the educational unit in developing the curriculum.

The development of Education Unit Level Curriculum (KTSP) that has been used in SMK in Samarinda then gradually shifted to the Curriculum 2013. Curriculum 2013 (K-13) is a curriculum applicable in the IndonesianEducation System. This curriculum is a permanent curriculum applied by the government to replace the Curriculum-2006 (often referred to as Education Unit Level Curriculum / KTSP) which has been valid for approximately 6 years.

In the implementation of the 2013 curriculum at SMK Forestry State Samarinda and SMK Muhammadiyah 3 Samarinda and the results of interview with the vice principal of curriculum, stated that there are still many obstacles, this is because not all teachers remain in both SMK know deeply about Curriculum 2013.

For teachers who have followed the workshop and training on the 2013 curriculum there are still many shortcomings in the field, so there are some learner materials that still apply the old curriculum, but gradually have begun implementing the 2013 curriculum.

\section{a. Teaching and learning process}

There are several learning concepts that can be used as a backdrop in developing learning in SMK, among others, as follows.

1. Technically and Vocational Education and Trainning (TVET) is designed to develop the full potential of learners in order to have job insight, technical skills to work, empower the skills, and transform themselves to changing the demands of the working world (Putu Sudira, 2016).

2. The first concept expressed by Charles A. Prosser (1950: 217) namely "vocational education will be efficient when learning (learners trained) by imitating the work environment as closely as possible with what happens in the actual workplace".

3. The second concept of Charles A. Prosser (1950: 218) "Learning in vocational education can be effective if training is conducted in the same way as in the world of work including the use of equipment and machinery".

4. The third concept of Charles A.Prosser (1950: 220) "Learning in vocational education will be effective according to proportion, if learning is directly and individually trained in learners in the habit of thinking and necessary habit manipulate it in the competence of expertise itself.

5. The concept of 21 st century learning is a model of science and engineering relations developed by Bernie Trilling and Charles Fadel (2009, adapted from Putu Sudira).

Learning with replication like the above concept is almost similar to Teaching Factory or Production Based Trainning / Production Based Education and Trainning which is a learning from the form of engineering and technology as a strategy of designing and finding solutions to the problems of life. As for the concept of science more emphasis method of investigation and discovery to explain the natural phenomena.

\section{b. Assessment Standards}

Assessment of the achievement of basic competencies by learners is based on GPA. Assessment is done using tests and nontes in both written and oral form, performance observation, attitude measurement, assessment of work in the form of tasks, projects and / or products, portfolio use, and self-assessment. Assessment is a series of activities to obtain, analyze, and interpret data about the process and learning outcomes learners are done in a systematic and sustainable, so that becomes meaningful information in decision making.

\section{Policy Evaluation on Output / Product components}

a. Graduate competence standard

Graduate Competency Standards (SKL) in Vocational Education is a criteria of graduate qualification that includes the dimensions of attitudes, knowledge, and skills that are expected to be achieved after 
the learners complete the learning. SKL is the main reference in the development of Core Competence $(\mathrm{KI})$, then Core Competence is translated into Basic Competence (KD).

To find out the achievement and conformity between Graduate Competency Standards and graduates from each education unit and curriculum used in certain education units, it is necessary to monitor and evaluate periodically and continuously in each period. The results obtained from monitoring and evaluation are used as input materials for the improvement of Graduate Competency Standards in the future.

The National Examination Scores for the last 3 years, namely the academic year 2014/2015, 2015/2016, and 2016/2017 can be seen in Table 3. Based on Table 3. It shows that from 3 subjects tested in National Examination for SMK Muhammadiyah 3 Samarinda, the value of mathematics subjects is the lowest, but from year to year has increased although not significant. On the other hand, for English and Indonesian subjects, there is a decrease in education.

The graduation percentage for SMK Forestry State Samarinda and SMK Muhammadiyah 3 Samarinda in the last three years graduated $100 \%$, and all graduates based on interview with their respective vice principals stated that some SMK graduates continue their study to university, most of them work and some small self-employed.

Table 3. National Exam Value (UN) 3 years Last of SMA Muhammadiyah 3 Samarinda

\begin{tabular}{clllllllll}
\hline & \multicolumn{3}{l}{ Indonesian } & \multicolumn{4}{c}{ English } & \multicolumn{3}{c}{ Mathematics } \\
\cline { 2 - 10 } Competence & UN & UN & UN & UN & UN & UN & UN & UN & UN \\
& $\mathbf{2 0 1 5}$ & $\mathbf{2 0 1 6}$ & $\mathbf{2 0 1 7}$ & $\mathbf{2 0 1 5}$ & $\mathbf{2 0 1 6}$ & $\mathbf{2 0 1 7}$ & $\mathbf{2 0 1 5}$ & $\mathbf{2 0 1 6}$ & $\mathbf{2 0 1 7}$ \\
\hline TITL & 62,13 & 60,29 & 58,22 & 44,29 & 40,86 & 37,33 & 22,50 & 32,14 & 30,55 \\
TKR & 56,02 & 57,88 & 53,71 & 35,58 & 45,27 & 30,57 & 23,41 & 25,23 & 25,88 \\
TAB & 56,54 & 59,42 & 62,08 & 36,86 & 46,65 & 38,17 & 23,58 & 27,86 & 29,56 \\
\hline
\end{tabular}

\section{b. Student achievement}

Students' achievements over the last three years, in addition to graduating $100 \%$ they also often follow the loba-loba, such as trials related to competencies such as electric LKS competitions, speech contests, Computer competitions and jugo loba-lombang in the field of sports such as chess, futsall and others, both city, provincial and national level. For SMK Muhammadiyah 3 Samarinda had won 1st LAMP list of Samarinda city level in 2015 and 2016, 1st Winner of Electrical LKS of Kaltim provincial level in 2016 and 2017, and 15 major LKS of National Electricity in Solo, Central Java in 2017. Besides student achievement, both schools have also implemented ISO 9001-2008 certification.

\section{B. Discussion}

Based on the results of research that the policy of Total Quality Management (TQM) in SMK city of Samarinda especially SMK Forestry State of Samarinda and SMK Muhammadiyah 3 Samarinda which have been based on ISO 9001-2008 is a necessity in improving the quality of education. In improving the TQM schools based on ISO 9001-2008 that run the 10 main elements need to be implemented continuously so that the system improves continuously.

The school quality assurance system consists of two major components: Internal Quality Assurance System and External Quality Assurance System. Internal Quality Assurance System (SPMI) is a quality assurance system that runs in educational units and is run by all components of the education unit. While the External Quality Assurance System (SPME) is a quality assurance system run by the government, local government, accreditation bodies and standards bodies.

By synergizing the two major components is a policy that must be implemented for schools that want to improve the quality of school.

\section{Evaluation in Context Components}

The need for TQM policy in SMK as improving the quality of school based on ISO 9001-2008 is 
needed in enhancing global competition. To improve the quality, the vision, mission and objectives of the School are needed in making Strategic Plan (Renstra) both in short, medium and long term. The vision must be clear when the time will be realized so that the steps that need to be done on the mission is clear. This is important so that the target can be achieved, but in reality many vision and mission is not clear when will be achieved. If the vision and mission is clear, then making the roadmap is also easy and clear as well and make the restra also more comfortable and appropriate.

\section{Evaluation in Inputs Components}

Discussion of the findings in the evaluation results of input components based on several aspects of curriculum, financing, facilities and infrastructure as well as educators and education personnel. From the results of interviews with the heads of SMK Forestry State Samarinda and SMK Muhammadiyah 3 Samarinda explained that all classes have implemented the 2013 curriculum, although it has not run properly in accordance with the applicable regulations that are in accordance with the Decree of Directorate General of Primary and Secondary Education Number 130 / D / KEP / KR / 2017 dated February 10, 2017 on the Curriculum Structure of Vocational Secondary Education.

With the declared decision dirjend then all existing SMK in Indonesia must have adjusted with the decision. The curriculum must be in accordance with the development and the current era of globalization, so that the curriculum is clearly willing to take where will our students in the future.

Financing in the implementation of education is very important, especially the routine expenses and expenses of employees such as honorarium salaries and salaries, especially private school schools need to be carefully planned so as not to cause problems that affect sangan influence on learners.

To increase the acceptance of the education budget is indeed required by the number of students, but it also needs to be noticed that the number of students does not meet the standards of others so as not to pinjang next door. Therefore it takes creativity in improving the source of funds from the state budget, APBN through Bosnas, Bosda and from the community through the School Committee.

Facilities and services have met the standards that have been set, but need to be budgeted in its maintenance, especially workshop and laboratory facilities, including the risk of accidents in work in this case in the workshop and laboratory. Educators have been mostly educated and master, but many still do not have educator certificates in accordance with the field he taught. This needs to be considered in improving the professional educator. Student acceptance, especially SMA Muhammadiyah 3 Samarinda still not meet the needs received so that the register can be accepted all, so the quality of student input is still low. This needs a strategy in increasing student interest for school in SMK.

\section{Evaluation in Process Components}

Implementation of the implementation of the implementation of the 2013 curriculum needs to be considered in the process of teaching and learning in the classroom, where the ways, methods and strateri in the learner in SMK have different approaches in SMU, where the emphasis on knowledge and skills are clear in applying that knowledge. Conceptually, learning on Vocational Education and Trainning (TVET) is designed to develop all potential learners in order to have job insight, technical skills working, empoyability skills, and transform themselves to changes in the demands of the world of work. In the process of teaching and learning in the classroom and in the workshop and laboratory needs to be considered comparison of teachers and students must follow the standards that have been set in accordance with standard processes are made.

\section{Evaluation in Product / Output Components}

Evaluation in the input component is an evaluation conducted to measure the achievement of the policy objectives made by schools in applying ISO-quality assurance system. To see the satisfaction of learners in education in SMK can be seen from the value of US, UN and productive value. The higher the value the better the teaching and learning process in schools, especially the value of competence in accordance with their competence. Student achievement in addition to the value can also be seen from the ektrakululerular prestsi in helping his curricular achievement. Schools that have implemented ISO 9001-2008, have been administratively meet the standards in accordance with existing standards, so it 
remains to see the commitment to the standards made, whether already implemented or not. Then also need to see the system of international quality assurance (BAN-SM) whether the accreditation can be A or not then new to International Accreditation.

\section{CONCLUSION AND SUGGESTION}

The background of the need to apply TQM in schools that implement the ISO as big as it has been running in accordance with the standards that have been determined because it is a demand for job market for learners of SMK as field technical personnel. The vision, mission and objectives of both vocational schools are good, but it needs clarity when the vision, mission and objectives will be achieved so as to make roadmadnya more clear and timely. The curriculum applied in both the ISO 9001-2008 based SMK has implemented the Curriculum 2013, but can not see the results because the new curriculum product has not yet passed the students. But the implementation still needs improvement-perfection.

The availability of funding in the implementation of teaching and learning process in schools that come from the government in this case through the state budget either directly or in the form Bosnas and Bosda and from the community in the form of Contribution of Learning Program (SPP) as well as other funds that are lawful and non-binding. Education facilities and infrastructure meets the standards set out in 8 national education standards and standards established through ISO. Educators and education personnel are adequate in accordance with educator standards and kependikan set either nationally or ISO standards. The 2013 curriculum that has been implemented in both vocational schools is well underway in the teaching and learning process at school and still make improvements in implementing it in the classroom and workshop and laboratory.

Implementing the teaching and learning process in accordance with predefined process standards, ranging from learning planning, implementation of learning and assessment in the learning process in accordance with the existing assessment format in the curriculum 2013. To see the satisfaction of learners in education in SMK can be seen from the value of US, UN and productive value. The higher the value the better the teaching and learning process in schools, especially the value of competence in accordance with their competence. Student achievement in addition to the value can also be seen from the ektrakululerular prestsi in helping his curricular achievement.

The willingness of SMK in Samarinda that apply TQM and ISO-based is very necessary, so need to be applied properly and continuously continuously hence needed suggestion as follows: (1) Should be socialized about the understanding of ISO-based TQM to all stakeholders in SMK so that not only the ISO team that understand the TQM-based ISO 9001-2008. It aims to support the success of TQM in schools, (2) Apart from discussing the internal audit and external audit should also discuss complaints from students where the implementation of ISO 9001-2008 is also intended to meet the needs of students expected, and (3) To raise the TQM based on ISO 9001-2008 well in reaching its tujaunnya it is necessary to note commitment, paradigm shift, mental attitude and organizing quality assurance system.

\section{REFERENCES}

Allen J, Putt, dan J.Fred Springer. (1989). Policy Research. New Jersey: Printice Hall.

Badan Standarisasi Nasional (BSN). (2008). Sistem Manajemen Mutu-Persyaratan.

Danim, Sudarwan. (2005). Pengantar Studi Penelitian Kebijakan. Jakarta: Bumi Aksara.

Daryanto. (2007). Evaluasi Pendidikan. Jakarta: Rineka Cipta.

Don E. Gardner. (1977). Five Evaluation Frameworks: Implications for Decision Making in Hihger Education. The Journal of Higher Education, Volume 48, Number 5.

Frederick, William C, Keith Davis and James E. Post. (1998). Business and Siciety, Coeporate Strategy, Public Policy, Ethics, sixth Edition. New York: McGraw-Hill Publishing Company.

Husaini Usman. (2016). Manajemen Teori \& Riset Pendidikan Edisi 4. Jakarta: Bumi Aksara.

Ipnugraha. (2012). Penerapan Sistem Manajemen Mutu ISO 9001:2000 di SMK N 2 Pengasih Kulon 
Progo. Jurnal Pendidikan Teknologi dan Kejuruan, Volume 21 No 1. Halaman 23-28.

Ipnugraha. (2012). Penerapan Sistem Manajemen Mutu ISO 9001:2000 di SMK N 2 Pengasih Kulon Progo. Jurnal Pendidikan Teknologi dan Kejuruan, Volume 34 No 2. Halaman 141-154

Kaufman, Roger and Susan Thomas. (1980). Evaluation Without Fear. Florida: Tallahassee.

LAN. (1993). Sistem Administrasi Negara. Jakarta: Haji Masagung.

Merrill, Charles E. (1990). Business Policy and Strategic Management. New York: Bell \& Howi Tli Company.

Mullins, Laurie J. (1999). Management and Organizational Behavior Second Edition. New Delhi: Wheeler Publishing.

Nugroho, Riant. (2008). Public Policy. Jakarta: Elex Media Komputido.

Riban, Amat Mukhadis, \& Isnandar. (2011). Implementasi ISO 9001:2000 Pada Produktif Bidang Keahlian Bagunan Di Sekolah Menengah Kejuruan.

Robinson 2002 CIPP to Approach Evaluation. COLLIT Project. Diakses dari http://www.swinburne.edu.au/spl/learningspacesproject/outcomes/files/SU T_Theoretica Framework.pdf. Pada tanggal 10 September 2017.

Sallis, Edward. (2012). Manajemen Mutu Terpadu Pendidikan. Yogyakarta: IRCiSoD.

Sudjana, Djudju. (2006). Evaluasi Program Pendidikan Luar Sekolah. Bandung: Remaja Rosdakarya.

Stufflebeam, Daniel L. and Antony J. Shinkfield, Systematic Evaluation, a Self-International Guide to Theory and Practice, Michigan: Kluwer-Nijhoff Publishing.

Syafaruddin. (2002). Manajemen Mutu Terpadu dalam Pendidikan Konsep, Strategi, dan Aplikasi. Jakarta: Grasindo.

Tangkilisan, Hessel Nogi S. Implementasi Kebijakan Publik. Yogyakarta: Lukman Ofset, 2003.

Tjiptono, Fandy \& Diana, Anastasia. (2003). Total Quality Management (TQM)- Edisi Revisi. Yogyakarta: Andi.

Wayne, Person. (1995). Public Policy. Edwar Elgar: Massachusett.

Widodo, Joko. (2007). Analisis Kebijakan Publik. Malang: Bayu Media.

William N. Dunn,(Terjemahan). (2000). Pengantar Analisis Kebijakan. Edisi Kedua, Yogyakarta: Gadjah Mada University Press. 